ENTREPRENEURSHIP AND SUSTAINABILITY ISSUES

ISSN 2345-0282 (online) http://jssidoi.org/jesi/

2020 Volume 7 Number 4 (June)

http://doi.org/10.9770/jesi.2020.7.4(25)

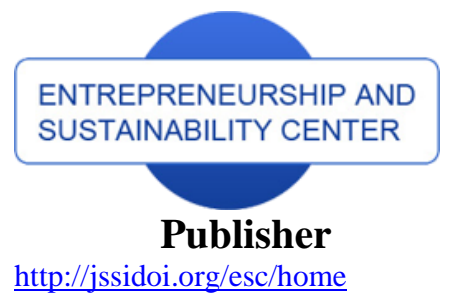

http://jssidoi.org/esc/home
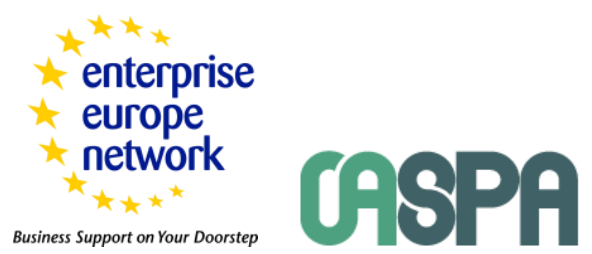

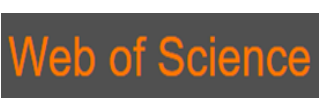

Clarivate
Analytics

\title{
DYNAMIC KNOWLEDGE MANAGEMENT CAPABILITY AND STRATEGIC INTUITION OF THAI ENTREPRENEURS*
}

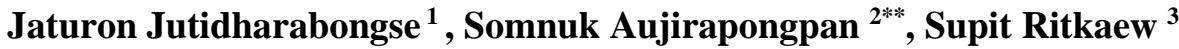 \\ ${ }^{1,2,3}$ School of Management, Walailak University, Nakhon Si Thammarat, 80160, Thailand \\ E-mails: ${ }^{1}$ cjaturon@wu.ac.th $;{ }^{2 * *}$ asomnuk@wu.ac.th (Correspondingauthor); ${ }^{3}$ supit.ritkaew@gmail.com
}

Received 11 January 2020; accepted 3 April 2020; published 30 June 2020

\begin{abstract}
The main objective of this research is to study the relationships in the causal influences of cognitive capability, absorptive capability, dynamic knowledge management capability and strategic intuition capability using the method of consistency testing on the structural equation models with empirical data. The research samples consisted of 342 SME provincial champions entrepreneurs under the office of small and medium enterprises promotion. The findings indicated that the hypothesized relationships between the independent and dependent variables fit the empirical data. Specifically, it reveals that cognitive capability, absorptive capability, dynamic knowledge management capability and strategic intuition capability well responded to the empirical data. However, on the development of dynamic knowledge management capability and strategic intuition, it was found out that a genuine wisdom development by systematic knowledge management through the state of awake mental concentration could lead to the next stage of strategic intuition.
\end{abstract}

Keywords: cognitive capability; absorptive capability; dynamic knowledge management; capability; strategic intuition capability; entrepreneur

Reference to this paper should be made as follows: Jutidharabongse, J., Aujirapongpan, S., Ritkaew, S. 2020. Dynamic knowledge management capability and strategic intuition of Thai entrepreneurs. Entrepreneurship and Sustainability Issues, 7(4), 2955-2966. http://doi.org/10.9770/jesi.2020.7.4(25)

JEL Classifications: L26, M10, M40, O15

\section{Introduction}

Thailand, at present, is in the process of changing the economic structure to an era of Value-Based Economy under the concept of Thailand 4.0 aimed to drive the country and making 3 dimensions change including 1) Changing from producing commodities to innovative products; 2) Changing from industrialization country to technological, creative and innovative country; 3) Changing from focusing on the product manufacturing to more services-oriented ( Office of the National Economic and Social Development Council, 2017). With the government's emphasis on encouraging entrepreneurs to use technology and innovation to help driving business, it

\footnotetext{
${ }^{*}$ This research was partially supported by the new strategic research $(P 2 P)$ project, and it also was supported by Institute of Research and Innovation, Walailak University, Thailand
} 


\section{ENTREPRENEURSHIP AND SUSTAINABILITY ISSUES}

ISSN 2345-0282 (online) http://jssidoi.org/jesi/

2020 Volume 7 Number 4 (June)

http://doi.org/10.9770/jesi.2020.7.4(25)

is found out that the trend of establishing a newly build business is of interest to a group of young entrepreneurs, which focuses on using creativity to create business opportunities and to make money grow faster (Export-Import Bank of Thailand, 2016). Therefore, it is very important for entrepreneurs to develop themselves to be capable to use information and knowledge, which are distributed in many places all over the world in order to develop their own learning process by integrating those knowledge together with the development of their own knowledge regularly.

Over the past 40 years, it is interesting that studies of business strategies of most entrepreneurs have focused on the strategic development to achieve long-term performance (Meers \& Robertson, 2007; Miller \& Cardinal, 1994; Venkatraman \& Ramanujam, 1986) which is actually considered difficult in the context of a fluctuating business environment (Grant, 2003). Some academics suggest that changes in a fluctuating environment require a flexible and constructive plan (Hamel, 1996), as well as a proactive, continuous and diverse organizational management process (Brown \& Eisenhardt, 1997). There are also discussions about the strategies that occur in organizations. Although there are planning efforts to change the environment, individual adjustments and actions, it is still necessary to learn more about the decisions and actions of individuals involved in organizational processes specially the viewpoint about the feelings, instincts and intuition of people in the organization. As can be seen from the research trends since 2000, researchers have placed importance on the study of strategies under the concept of intuition, which is continuously increasing and can explain the changing of the concentration on the study of strategies in different ways (Teece, 2018)

\section{Theoretical Background}

Nowadays, organizations or businesses focus on using knowledge as the basis for business strategy (KnowledgeBased View) Therefore, the development of knowledge resources that are essential to the organization, paly the main role and must be carried out in accordance with the plan or target set to create a sustainable and long-term competitive advantage (Barney, 1991; Kogut \& Zander, 1992). Haggie and Kingston (2003) discussed the strategy of knowledge management in each organization and formulated 3 different focus points: Knowledge Focus; Business Process Focus; and End Result Focus. The formulation of knowledge management strategies must be consistent with and unified in the formulation of business strategies in order to be successful (Zack, 1999; Greiner, Bohmann \& Krcmar, 2007). As for determining a form and a focus point of knowledge management strategies, it depends on the environment, context and goals of the organization (Haggie \& Kingston, 2003).

From the previous knowledge management concepts, it is found out that most of the researchers focus on the study of specific issues in a modular way, whether it is an individual context that is related to the process of knowledge management or the organizational context, which is a component of most factors that facilitate knowledge management. The choice of an appropriate knowledge strategy brings to its implementation through a process of knowledge management cycle, consisting of knowledge acquisition, sharing, development, preservation and application of it. (Raudeliūnienè, Davidavičienè \& Jakubavičius, 2018). According to previous research, it is found out that entrepreneurs who value the integration of intellectual resources through knowledge management processes and conducting basic learning activities of the organization will be able to increase competitive advantage (Crossan, Lane \& White, 1999). In this process, Gannon, Lynch and Harrington (2009) developed a Dynamic Knowledge Management capability model. Therefore, to be successful or fail in conducting business, top priority factors include perspectives, ideas and decision-making process of entrepreneurs in choosing strategies for organizational problems to eliminate defects and plan work in accordance with the organization's vision (Kouzes \& Posner, 2012; Duggan, 2013). One of the key capabilities of successful business entrepreneurs is the ability to recognize future possibilities for conducting business toward its goal without having to rely on predictions or apply rational information to make decisions. It is however the use of feelings, instinct combined with one's own experience in making decisions about a particular matter ( Teece, 2018). These 


\section{ENTREPRENEURSHIP AND SUSTAINABILITY ISSUES}

ISSN 2345-0282 (online) http://jssidoi.org/jesi/

2020 Volume 7 Number 4 (June)

http://doi.org/10.9770/jesi.2020.7.4(25)

capabilities are referred to under the name of "wisdom" or "insight". For these reasons, the researcher is interested to study the important components and ways to develop such capabilities in order to increase the business potential for Thai entrepreneurs and enhance the business competitive advantage in Thailand to conform with the government policy in bringing the country to Thailand 4.0.

\section{Conceptual Background and Hypothesis}

\subsection{Cognitive Capability}

Davenport and Prusak (1998) said that knowledge would not be transferred entirely without support from the absorptive capability. Similarly, Szulanski (1996) shows that the transfer of knowledge in organizations becomes a big obstacle if it is not supported by the absorptive capability as well. Therefore, it can be seen that the sharing of knowledge and the knowledge absorptive capability are interconnected and cannot be separated. Zahra and

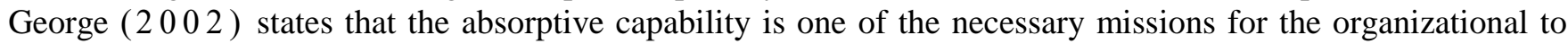
identify and use knowledge, which reflects the economic ability to use and absorb information.

\section{$\mathrm{H}_{1}$ : Cognitive capability directly and positively affects absorptive capability.}

In the current study, it is found out that most entrepreneurs emphasized on the integration of intellectual resources through knowledge management processes and carry out basic learning activities of the organization. The aim is to increase competitive advantage (Crossan, et al. 1999). Gannon et al. (2009) developed a dynamic knowledge management capability model by placing importance on 3 main components: Intellectual Resource Management; Knowledge Management; and Organizational Learning Management, which are one of the cognitive capability components.

\section{$\mathrm{H}_{2}$ : Cognitive capability directly and positively affects dynamic knowledge management capability.}

Gannon et al. (2 009 ) emphasized on intellectual resource management, which consists of Human Capital, Structural Capital and Relational Capital. These can be seen as a group of resources that are unstable and cannot survive without helps from their components, both individuals and organizations (Daft \& Weick, 1984). The development of dynamic knowledge management capabilities requires the integration of all three components by using the absorptive capability that combines knowledge from both inside and outside the organization.

\section{$\mathrm{H}_{3}$ : Cognitive capability directly and positively affects strategic intuition capability.}

\subsection{Absorptive Capability}

Aujirapongpan and Jutidharabongse (2017) mentioned that strategic intuition is linked to knowledge management concepts as a starting point for the intelligible skills development that requires knowledge and experience existing in human. It is used as a base for the development in which the definition of knowledge in person's related dimensions is a result of the wisdom and learning that exists in all people. It is considered an important element in making the organization successful. The knowledge and experience each person have are general knowledge and professional knowledge. Therefore, it can be seen that knowledge and experience are dynamic, arising from the interaction between individuals and individuals or individuals and organizations by exchanging various ways of Tacit Knowledge and Explicit Knowledge in organizations.

$\mathrm{H}_{4}$ : Absorptive capability directly and positively affects dynamic knowledge management capability. 


\section{ENTREPRENEURSHIP AND SUSTAINABILITY ISSUES}

ISSN 2345-0282 (online) http://jssidoi.org/jesi/

2020 Volume 7 Number 4 (June)

http://doi.org/10.9770/jesi.2020.7.4(25)

Aujirapongpan and Jutidharabongse (2017) also discussed that in order to upgrade knowledge management to the development of Strategic Intuition Capability, aside from that person having such cognitive capabilities, it is important to have skills to understand what one has learned and what has happened and to capture important issues from the awareness effectively in order to use the information to synthesize techniques, strategies for implementing in accordance with the changing environment.

\section{$\mathrm{H}_{5}$ : Absorptive capability directly and positively affects strategic intuition capability.}

\subsection{Dynamic Knowledge Management Capability}

Gannon et al. (2009) says that the current strategic management theory has changed the concept of focusing on external environment to internal resources that can be controlled within the organization. It can be seen that the potential to create a competitive advantage comes from wisdom capital in the form of relational and structural human resources ( Čirjevskis, 2015;Teece, 2018). The ability of people in the organization to rethink, redo, proceed with synthesis, apply and develop knowledge constantly, is important to define an operational strategy that requires people with rational thinking and can result in the strategic intuition capability. capability.

$\mathrm{H}_{6}$ : Dynamic knowledge management capability directly and positively affects strategic intuition

\subsection{Strategic Intuition Capability}

Duggan (2013) gave a definition of strategic intuition: strategic intuition is a scientific phenomenon that occurs from the use of good ideas and reasoning through past experiences to solve problems in the future that have never been seen before (Ahangaran, Khooshebast, \& Vahedi, 2016). Dane and Pratt (2007) described the strategic intuition as a form of brain processing in an easy-to-use format. It happens beyond conscious thinking, holistic connection through environmental stimulation. Over the past decades, studies on intuition have stepped forward in behavioral sciences by expanding the scope of the study to the branch of social neurology. In this regard, Hodgkinson, Smith, Burke, Claxton and Sparrow (2009) studied the matter of and have identified the key elements for organization executives in enhancing intuition capability, namely 1) Acquiring Intuition Expertise; 2) Developing Self Awareness; 3) Managing Strategic Decision Making and; 4) Creative Situations.

However, basically a person who have intuition capability must initially have knowledge and expertise in the field well enough. This is one aspect of Knowledge Based Capability View, which is a factor that affects knowledge management capability as well. For example, those who have the smart knowledge and expertise are the ones who are capable of doing something well, which results from having unique knowledge and arising from experience, training and cooperation. People with expertise or people with knowledge and ability are considered people who have the Knowledge Champions and is important to the organization knowledge development. This will play a very important role in knowledge transfer or knowledge exchange (Hansen, Nohria \& Tierney, 1999 ; Jones, Herschel \& Moesel, 2003 ). The organization should create a career path for those experts (Alavi \& Leidner, 2001), because each expert can create a creative team (Tiwana \& Mclean, 2005). They will always be those who need new knowledge from the outside (Dooley, Corman \& McPhee, 2002; Figurska, 2014) and will increase Tacit Knowledge (Gurteen, 1998) including the ability to transfer knowledge which means the ability to transform from hidden knowledge to clear knowledge as well (Raudeliūnienè et al, 2018). 


\section{Methodology}

\subsection{Population and Sampling}

The researcher determined entrepreneurs in Thailand as the population of the current research using the database of small and medium enterprises which participated the SME Provincial Champions 2018 project of the office of small and medium enterprises promotion. There are 450 cases (Export-Import Bank of Thailand, 2018). The researcher also specify the sample size equal to the population. The researcher sent the questionnaire to the population within the database-there are 450 cases and followed up every week in one month. However, at the end of the specified time, it was found out that 342 respondents were recorded, accounting for 76 percent of the total population. Regarding the business types, the entrepreneurs who responded to the questionnaire can be classified into subgroups as follow in Table 1:

Table 1. Business type of entrepreneur $(n=342)$

\begin{tabular}{|c|c|c|}
\hline Business type & frequency & percent \\
\hline Food and drink & 203 & 62.1 \\
\hline Clothes & 41 & 12.0 \\
\hline Tourism and accommodation & 50 & 14.6 \\
\hline health and beauty & 23 & 6.7 \\
\hline jewelry & 16 & 4.7 \\
\hline appliance & 8 & 2.3 \\
\hline electronics & 1 & 0.3 \\
\hline
\end{tabular}

\subsection{Data analysis}

A questionnaire was used as the tool to collect the data in the current research. The 5 level Likert scale was used to measure individual aspects of opinion. It was pretested with 30 businesses. Then, the data collected were analyzed to test the reliability of the questionnaire using Cronbach's alpha coefficient in Table 2 . The results of the reliability test of each construct are between 0.895 and 0.793 . The questionnaire has a high level of reliability, as Nunnally (1978) and Cortina (1993) pointed out that the reliability score should be more than 0.7. And the basic statistical values such as frequency, percentage, mean, standard deviation, Chi-Square, alpha coefficient Pearson's correlation coefficient, KMO statistics and Bartlett's Test statistics for finding out the characteristics of the respondents were analyzed using the SPSS program. In addition, the relationships between various components from the empirical data of entrepreneurs in Thailand based on the research hypothesis set were also analyzed using the structural equation modeling through reading the analysis from Pearson's correlation analysis and path analysis in the congeneric measurement model. The statistical value that will be used to check the consistency of the research model and the empirical data based on the research hypothesis are Chi-Square, Goodness of Fit Index (GFI) and Adjusted Goodness of Fit Index - AGFI).

Table 2. Result of reliability test

\begin{tabular}{lcc}
\hline \multicolumn{1}{c}{ Variables } & Construct & Cronbach's Alpha \\
\hline Cognitive Capability & COG & 0.795 \\
Absorptive Capability & ABS & 0.895 \\
Dynamic Knowledge Management Capability & DKMC & 0.863 \\
Strategic Intuition Capability & SIC & 0.793 \\
\hline
\end{tabular}




\section{Results}

The analysis of the causal influence to study the relationship of the structural equations shows that the variables used in the analysis should have the characteristics of the normal distribution (normality). As for the significance test of skewness and kurtoris using LISREL program as in Table 3 it was found out that the cognitive capability variables (COG), the absorptive capability variable (ABS), the dynamic knowledge management capability (DKMC) with the influence on the strategic intuition capability (SIC) had an abnormal distribution with statistical significance at the level of 0.05 . Regarding the data analysis to test the consistency of the model and the empirical data, the model analysis results were consistent with empirical data which is reliable in Table 3.

Table 3. Distribution for analyzing the relationships of variables

\begin{tabular}{ccccccc}
\hline \multirow{2}{*}{ Variables } & \multicolumn{2}{c}{ Skewness } & \multicolumn{2}{c}{ Kurtosis } & \multicolumn{2}{c}{ Skewness and Kurtosis } \\
\cline { 2 - 7 } & Z-Score & P-Value & Z-Score & P-Value & Chi-Square & P-Value \\
\hline COG & -2.015 & 0.224 & 1.769 & 0.341 & 0.139 & 0.025 \\
ABS & -3.938 & 0.013 & 1.962 & 0.003 & 1.872 & 0.933 \\
DKMC & -2.269 & 0.008 & -0.168 & 0.136 & 7.148 & 0.010 \\
SIC & 0.154 & 0.137 & 1.406 & 0.734 & 7.505 & 0.028 \\
\hline
\end{tabular}

From the Pearson's correlation coefficient analysis of all variables used in the analysis, there is a statistically significant linear relationship at the level of 0.01 indicating that the variables used in the analysis has rectilinear relationship between variables. In addition, the researcher evaluated the effectiveness of the measurement model Considering the Relative Variance $(\rho \mathrm{C})$ and the Average Variance Extracted $(\rho \mathrm{v})$, and it shows that the variance of each variable in each component is relatively low ( $\rho v>0.50)$, as in Table 4.

Table 4. Discriminant validity analysis

\begin{tabular}{|c|c|c|c|c|c|c|}
\hline \multirow{2}{*}{ Construct } & \multicolumn{4}{|c|}{ Cross construct correlation } & \multirow[b]{2}{*}{$\rho \mathrm{C}$} & \multirow[b]{2}{*}{$\rho \mathrm{v}$} \\
\hline & $\mathrm{COG}$ & ABS & DKMC & SIC & & \\
\hline $\mathrm{COG}$ & 1.00 & & & & 0.6812 & 0.5616 \\
\hline ABS & $0.76^{* *}$ & 1.00 & & & 0.8892 & 0.6747 \\
\hline DKMC & $0.54 * *$ & $0.48 * *$ & 1.00 & & 0.7841 & 0.6457 \\
\hline SIC & $0.52 * *$ & $0.41 * *$ & $0.46 * *$ & 1.00 & 0.7671 & 0.6329 \\
\hline
\end{tabular}

When considering the basic terms for analyzing the causal influence of the structural equations as detailed above, the researcher then analyzed the data with LISREL program. From the analysis of causal influences with latent variables between cognitive capability, absorptive capability, dynamic knowledge management capability, and the strategic intuition capability, found that the model is not consistent with the empirical data at the first time of data analysis. The researcher then adjusted the model until the model was consistent with the empirical data by considering Chi-Square, P-Value, GFI, AGFI, RMSEA and RMR as in Table 5. 
Table 5. Causal influences

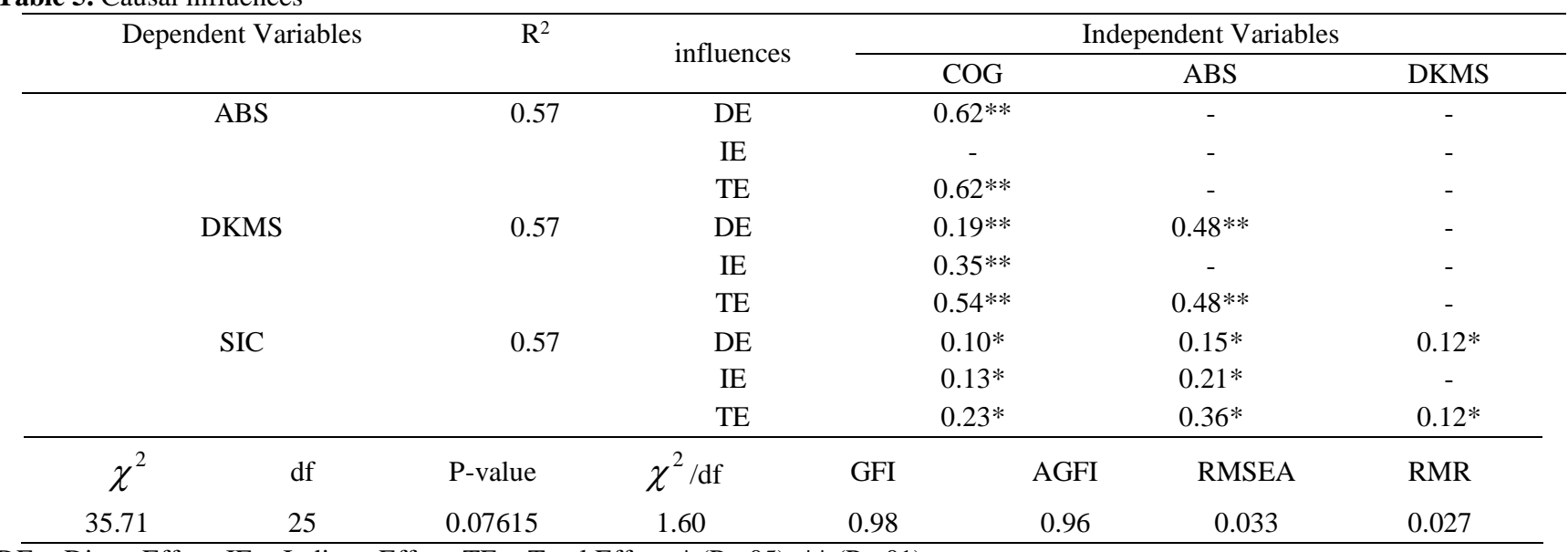

$\mathrm{DE}=$ Direct Effect, IE = Indirect Effect, TE = Total Effect, $*(\mathrm{P}<.05), * *(\mathrm{P}<.01)$

Tables 4 and 5 show that the hypothesis testing results using Pearson's correlation coefficient of all variables has a statistically significant positive value at the level of 0.01 . In addition, when analyzing the causal relationship of all variables, it was found out that all variables had the level of causes with statistical significance at the level of 0.01 and 0.05 as in figure 1 .

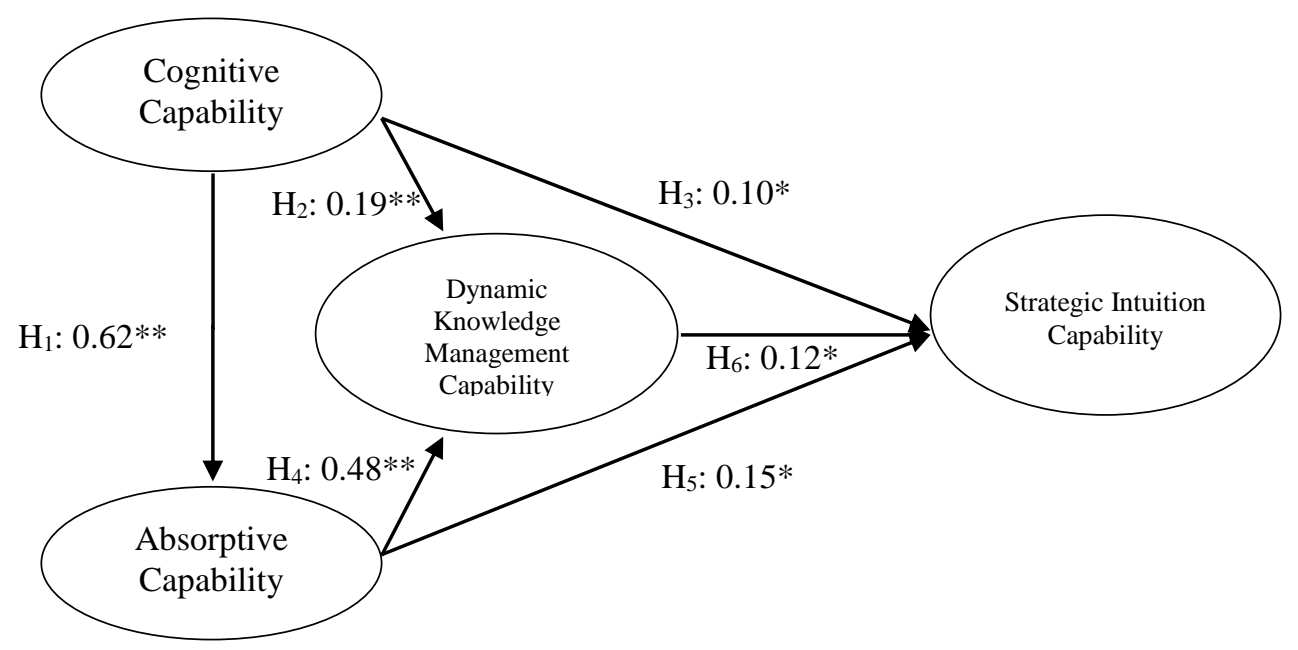

Chi-Square $=35.71, \mathrm{df}=25, \mathrm{P}$-value $=0.07615, \mathrm{GFI}=0.98, \mathrm{AGFI}=0.96, \mathrm{RMSEA}=0.033$, $\mathrm{RMR}=0.027, * \mathrm{P}<0.05, * * \mathrm{P}<0.01$

Figure 1. The structural equation model 


\section{ENTREPRENEURSHIP AND SUSTAINABILITY ISSUES}

ISSN 2345-0282 (online) http://jssidoi.org/jesi/

2020 Volume 7 Number 4 (June)

http://doi.org/10.9770/jesi.2020.7.4(25)

\section{Conclusions and Discussion}

When considering the results of the structural model analysis or the path coefficient of cognitive capability, absorptive capability, dynamic knowledge management capability and the strategic intuition capability, it was found out that every variable has a positive influence. cognitive capability variable has a causal influence on absorptive capability, dynamic knowledge management capability and strategic intuition capability, equal to 0.62 $(\mathrm{SE}=0.08, \mathrm{t}=1.72), 0.19(\mathrm{SE}=0.20, \mathrm{t}=3.67), 0.10(\mathrm{SE}=0.10, \mathrm{t}=1.16)$. Absorptive capability has a causal influence on dynamic knowledge management and strategic intuition capability, equal to 0.48 ( $\mathrm{SE}=0.07, \mathrm{t}=$ 4.11) and $0.15(\mathrm{SE}=0.07, \mathrm{t}=0.63)$ respectively. Moreover, it was found that the dynamic knowledge management capability has a causal influence on the strategic intuition capability, equal to 0.12 ( $\mathrm{SE}=0.06, \mathrm{t}=$ 2.22) with statistical significance at the confidence level of 0.05 and 0.01 . From the hypothesis testing using Pearson's correlation coefficient analysis, all variables have a positive relationship with each other with statistical significance at the level of 0.01 .

However, when analyzing the causal influence relationship of cognitive capability of entrepreneurs in Thailand, it was found out that the causal influence on absorptive capability with statistical significance at the level of 0.01 corresponds to the concept of Zahra and George (2002) which stated that absorption is one of the organizational tasks necessary to identify and use knowledge, which reflects the economic ability to use and absorb information. When analyzing the causal influence relationship of cognitive capability of entrepreneurs in Thailand, it was found out that there was a causal influence on the dynamic knowledge management capability with statistical significance at the level of 0.01 . This is because most entrepreneurs give priority to the integration of intellectual resources through knowledge management processes and conduct basic learning activities of the organization with the aim of increasing competitive advantage (Crossan et al, 1999). Moreover, when analyzing the causal influence relationships in cognitive capability of entrepreneurs in Thailand, it was found out that there is a causal influence on the strategic intuition capability with statistical significance at the level of 0.05 . This is in accordance with Aujirapongpan and Jutidharabongse (2017) which says that at the initial point for beginning the development of intuitive skills the knowledge and experience that a person has are required as a base for the development.

The definition of knowledge in the dimensions relating to person is a result of the wisdom and learning that exists in all people. In addition, when analyzing the causal influential relationship concerning with absorptive capability of entrepreneurs in Thailand, it was found out that there is a statistically significant influence on the dynamic knowledge management capability at the level of 0.01. This is in accordance with what Gannon et al. (2009), who place importance on the intellectual resources management, which consisting of human capital, structural capital and relational capital, suggested. It can be seen that a group of unstable resources that cannot survive without the help of individual and organizational elements (Daft \& Weick, 1984). When analyzing the causal influential relationships concerning with the absorptive capability of entrepreneurs in Thailand, it was found out, in accordance with with Aujirapongpan and Jutidharabongse (2017), that there was a causal influence on the strategic intuition capability with statistical significance at the level of 0.05 .It was also found that to enhance of knowledge management to the strategic intuition capability, apart from a person having the cognitive capability, there needs to be skills of learning comprehension and occurrence. However, in analyzing the causal influential relationship of the dynamic knowledge management capability of entrepreneurs in Thailand, it was found out that there is a causal influence on the strategic intuition capability with statistical significance at the level of 0.05 , in accordance with Gannon et al. (2009)in that the current strategic management theory has changed the concept of focusing on the external environment to focusing on internal resources that can be controlled within the organization. This means that the ability to build competitive advantages is created by intellectual capital in the form of relational and structural human resources (Teece, 2018). The ability of people in an organization to innovate, to synthesize systemically, to apply and develop knowledge constantly are important to specify an operational strategy that requires people with rational thinking and can result in the strategic intuition capability. 


\section{ENTREPRENEURSHIP AND SUSTAINABILITY ISSUES}

ISSN 2345-0282 (online) http://jssidoi.org/jesi/

2020 Volume 7 Number 4 (June)

http://doi.org/10.9770/jesi.2020.7.4(25)

\section{Implications}

This paper describes the relationships related to enhancing the dynamic knowledge management capability and the strategic intuition capability of entrepreneurs in Thailand to create a competitive advantage (Barney, 1991; Kogut \& Zander, 1992). Regarding the development of the dynamic knowledge management capabilities, it is evident that entrepreneurs must give priority to the development of knowledge within the organization. The business operations conducted by most entrepreneurs in Thailand reflect the knowledge management capability in a knowledge-based perspective that will help develop the ability to manage knowledge of the organization and can lead to the creation of strategic intuition capability (Teece, 2018). In this regard, having the dynamic knowledge management capability will be the basis for the development of entrepreneurial intelligence to the core and then will enter a state beyond consciousness, having a mind that is concentrated, resulting in the work of the brain and body systems are more efficient, making it possible to fully utilize its potential whether in work, thinking, decision making or problem solving. Ready to enter the state of wisdom, develop into a strategic intuition capability.

\section{Limitation}

This research is a compilation of data from small and medium-sized enterprises. Over $60 \%$ of respondents were entrepreneurs in the food and beverage business. As a result, the analysis results may not be able to directly represent each business group Therefore, in the next study, there should be a study and a balanced proportion of the business groups or it possibly be extended to a group of entrepreneurs who have been promoted and developed their competitive potential along with the government's policies, such as start-up entrepreneurs.

\section{References}

Ahangaran, J., Khooshebast, F., \& Vahedi, E. (2016). Meta-analysis of the effects of spirituality in the organization and comprehensive. International Journal of Advanced and Applied Sciences, 3(1), 22-31. http://www.science-gate.com/IJAAS/Articles/2016-31/04\%202016-3-1-pp.22-31.pdf

Alavi, M. \& Leidner, D. E. (2001). Review: Knowledge management and knowledge management systems: Conceptual foundations and research issues. MIS Quarterly, 25(1), 107-136. https://doi.org/10.2307/3250961

Aujirapongpan, S. \& Jutidharabongse, J. (2017). Strategic intuition: The development of leader in the 21st century. WMS Journal of Management, 6(3), 125-133. https://www.tci-thaijo.org/index.php/wms/article/view/99800?articlesBySameAuthorPage=2

Barney, J. (1991). Firm resources and sustained competitive advantage. Journal of Management, 17(1), 99-121. http://www.business.illinois.edu/josephm/BA545_Fall\%202019/Barney\%20(1991).pdf

Brown, S. L. \& Eisenhardt, K. M. (1997). The art of continuous change: Linking complexity theory and time-based evolution in relentlessly shifting organizations. Administrative Science Quarterly, 42(1), 1-34. https://doi.org/10.2307/2393807

Cortina, J. M. (1993). What is coefficient alpha? An examination of theory and applications. Journal of Applied Psychology, 78(1), 98-104. https://doi.org/10.1037/0021-9010.78.1.98

Crossan, M. M., Lane, H. W. \& White, R. E. (1999). An organisational learning framework: Fromintuition to institution. The Academy of Management Review, 24(3), 522-537. https://doi.org/10.5465/amr.1999.2202135

Daft, R. L. \& Weick, K. E. (1984). Toward a model of organisations as interpretation systems. Academy of Management Review, 9(2), 284295. https://doi.org/10.2307/258441 


\section{ENTREPRENEURSHIP AND SUSTAINABILITY ISSUES}

ISSN 2345-0282 (online) http://jssidoi.org/jesi/

2020 Volume 7 Number 4 (June)

http://doi.org/10.9770/jesi.2020.7.4(25)

Dane, E. \& Pratt, M. G. (2007). Exploring intuition and its role in managerial decision-making. Academy of Management Review, 32(1), 33-54. https://psycnet.apa.org/doi/10.2307/20159279

Davenport, T. H., Long, D. W. D. \& Beers, M. C. (1998). Successful knowledge management projects. Sloan Management Review, 39(2), 43-57. https://sloanreview.mit.edu/article/successful-knowledge-management-projects/

Dooley, K. J., Corman, S. R. \& McPhee, R. D. (2002). A knowledge directory for identifying experts and areas of expertise. Human Systems Management, 21(4), 217-228. https://content.iospress.com/articles/human-systems-management/hsm515

Duggan, W. (2013). Strategic intuition: The creative spark in human achievement (2nd ed.). NY: Columbia Business School.

Export-Import Bank of Thailand. (2016). Future startup trends, opportunities that entrepreneurs should not miss. https://kmc.exim.go.th/detail/knowledge-exim/20190702185432101

Export-Import Bank of Thailand. (2018). SME provincial champions. https://www.exim.go.th/en/Newsroom/Press-Releases1.aspx

Gannon, C., Lynch, P. \& Harrington, D. (2009). Dynamic knowledge management capability (DKMC): From resources to capital (RIKON Group). In: EIASM 5th workshop on visualising, measuring, and managing intangibles and intellectual capital. http://repository.wit.ie/id/eprint/1468

Grant, R. M. (2003). Strategic planning in a turbulent environment: Evidence from the oil majors. Strategic Management Journal, 24(6), 491-517. https://doi.org/10.1002/smj.314

Greiner, M. E., Bohmann, T. \& Krcmar, H. (2007). A strategy for knowledge management. Journal of Knowledge Management, 11(6), 315. https://doi.org/10.1108/13673270710832127

Gurteen, D. (1998). Knowledge, creativity and innovation. Journal of Knowledge Management, 2(1), 5-13. https://doi.org/10.1108/13673279810800744

Haggie, K. \& Kingston, J. (2003). Choosing your knowledge management strategy. Journal of Knowledge Management Practice, Retrieved from https://www.researchgate.net/publication/224968523_Choosing_Your_Knowledge_Management_Strategy

Hansen, M. T., Nohria, N. \& Tierney, T. (1999). What's your strategy for managing knowledge?. Harvard Business Review, 77(2), 106116. https://hbr.org/1999/03/whats-your-strategy-for managing-knowledge

Hamel, G. (1996). Strategy as revolution. IL: Harvard Business Review. https://hbr.org/1996/07/strategy-as-revolution

Hodgkinson, G. P., Smith, E. W., Burke, L. A., Claxton, G. \& Sparrow, P. R. (2009). Intuition in organizations: Implications for strategic management. Long Range Planning, 42, 277-297. https://doi.org/10.1016/j.lrp.2009.05.003

Jones, N. B., Herschel, R. T. \& Moesel, D. D. (2003). Using knowledge champions to facilitate knowledge management. Journal of Knowledge Management, 7(1), 49-63. https://doi.org/10.1108/13673270310463617

Kogut, B. \& Zander, U. (1992). Knowledge of the firm, combinative capabilities, and the replication of technology. Organization Science, 3(3), 383-397. https://doi.org/10.1287/orsc.3.3.383

Kouzes, J. M. \& Posner, B. Z. (2012). The leadership challenge: How to make extraordinary things happen in organizations (5th ed.). SF: Jossey-Bass.

Meers, K. A. \& Robertson, C. (2007). Strategic planning practices in profitable small firms in the United States. The Business Review Cambridge, 7(1), 302-307. http://www.jaabc.com/brcv7n1 preview.html

Miller, C. C. \& Cardinal, L. B. (1994). Strategic planning and firm performance: A synthesis of more than two decades of research. Academy of Management Journal, 37(6), 1649-1665. https://doi.org/10.2307/256804

Nunnally, J. C. (1978), "Psychometric Theory”, 2nd ed. McGraw Hill, New York.

Office of the National Economic and Social Development Council. (2017). The National Economic and Social Development Plan 12th (2017-2021). https://www.nesdb.go.th/nesdb_en/ewt_w3c/ewt_dl_link.php?nid=4345 


\section{ENTREPRENEURSHIP AND SUSTAINABILITY ISSUES}

ISSN 2345-0282 (online) http://jssidoi.org/jesi/

2020 Volume 7 Number 4 (June)

http://doi.org/10.9770/jesi.2020.7.4(25)

Raudeliūnienè, J., Davidavičienè, V., Jakubavičius, A. (2018). Knowledge management process Model. Entrepreneurship and Sustainability Issues, 5(3), 542-554. https://doi.org/10.9770/jesi.2018.5.3(10)

Szulanski, G. (1996). Exploring internal stickiness: Impediments to the transfer of best practice within in the firm. Strategic Management Journal 17(2), 27-43. https://doi.org/10.1002/smj.4250171105

Teece, D.J. (2018). Business models and dynamic capabilities. Long Range Planning. 51(1), 40-49. https://doi.org/10.1016/j.lrp.2017.06.007

Tiwana, A. \& Mclean, E. R. (2005). Expertise integration and creativity in information systems development. Journal of Management Information Systems, 22(1), 13-43. https://doi.org/10.1080/07421222.2003.11045836

Venkatraman, N. \& Ramanujam, V. (1986). Measurement of business performance in strategy research: A comparison of approaches. Academy of Management Review, 11(4), 801-814. https://doi.org/10.2307/258398

Zack, M. H. (1999). Developing a knowledge strategy. California Management Review, 41(3), 125-145. http://www.sbgc.org.br/uploads/6/5/7/6/65766379/zack1999.pdf

Zahra, S. A. \& George, G. (2002). Absorptive capacity: A review, reconceptualization and extension. Academy of Management Review, 27(2), 185-203. https://doi.org/10.5465/amr.2002.6587995

\section{Acknowledgements}

This research was partially supported by the new strategic research (P2P) project, Walailak University, Thailand. And it also was supported by Institute of Research and Innovation, Walailak University. 


\section{ENTREPRENEURSHIP AND SUSTAINABILITY ISSUES}

ISSN 2345-0282 (online) http://jssidoi.org/jesi/

2020 Volume 7 Number 4 (June)

http://doi.org/10.9770/jesi.2020.7.4(25)

Jaturon JUTIDHARABONGSE, Ph.D. Candidate in business administration from Walailak University, is a research assistant of Graduate Study in Innovation Management and Business Development, School of Management, Walailak University, Thailand. His publications have appeared in various national academic journals about knowledge management and human resource development.

ORCID ID: orcid.org/0000-0002-1571-778X

Somnuk AUJIRAPONGPAN, Ph.D., is an associate professor in accounting and director of graduate study in innovation management and business development, School of Management, Walailak University, Thailand. He received his Ph.D. in technopreneurship and innovation management from Chulalongkorn University. His professional expertises are managerial accounting, cost accounting, knowledge management, innovation management and entrepreneurship development. His publications have appeared in various national and international academic journals about accounting, entrepreneurship and business management. He also is a corresponding author of this article who provides the intellectual input, designs and approves the protocols to be followed in the study.

ORCID ID: orcid.org/0000-0001-6275-9053

Supit RITKAEW, Ph.D., is an assistant professor in applied mathematics of Innovation Management and Business Development Graduate Study Program of Walailak University. He received his Ph.D. in applied mathematics from University of Innsbruck, Austria. His professional expertises are business analytics, statistics and forecasting. And his publications also have appeared in various national academic journals about business analytics and entrepreneurship.

ORCID ID: orcid.org/0000-0003-0543-7730

Register for an ORCID ID:

https://orcid.org/register

Copyright (C) 2020 by author(s) and VsI Entrepreneurship and Sustainability Center

This work is licensed under the Creative Commons Attribution International License (CC BY).

http://creativecommons.org/licenses/by/4.0/

(c) (i) Open Access 